\title{
MENEPIS HOAX MELALUI PENDIDIKAN KARAKTER DAN PEMBELAJARAN SASTRA
}

\author{
Sri Widayati *) \\ Wied_stkip@yahoo.co.id \\ Pendidikan Bahasa dan Sastra Indonesia \\ Universitas Muhammadiyah Kotabumi
}

\begin{abstract}
Hoax is one of social media evil. It is not only happen on adult, but also on children. Hoax brings negative effect for society, especially for children because they will have a bad behavior. So to solve this problem, they need character education. Character education is one of education to improve values of nation characters on students. Character education will be successful with litration culture, that is literature learning. The students will face directly about live value of figures, such as religion value, honestly, tolerance, love, justice, and service. By internalization that value, hopely the students will avoid from hoax activities.
\end{abstract}

Kata Kunci: hoax, pendidikan karakter, pembelajaran sastra

\section{Pendahuluan}

Belum hilang dalam ingatan kita tentang hoax yang dilakukan oleh Ratna Surampaet. Ia mengaku telah dipukuli oleh beberapa oknum sehingga wajahnya penuh lebam. Cerita yang beredar saat itu katanya dia dihajar beberapa orang ketika berada di Bandung, tepatnya di Bundaran Husein Sastranegara pada tanggal 21 September 2018.Ternyata apa yang dilakukan Ratna hanyalah sebagai sebuah kebohongan yang ia sampaikan pada keluarganya. Kemudian kebohongan itu tersebar di media sosial melalui sejumlah akun. Namun, naas baginya karena kebohongannya itu justru diperkarakan. Ia terancam Undang-Undang
Informasi dan Transaksi Elektronik. Perilaku Ratna Sarumpaet tersebut kemudian diikuti juga oleh seorang anak yang bernama Audrey, siswa sekolah menengah pertama.

Audrey di bulan April 2019 menjadi trending topik dengan tagar \#Justice for Audrey\# di twitter. Banyak cuitan yang muncul di mesin telusur untuk mendukung Audrey yang diisukan telah dikeroyok oleh dua belas kakak tingkatnya. Bahkan, petisi online telah ditandatangani oleh hampir tiga juta pengguna internet. Kasus ini bukan hanya sampai ke telinga para netizen, melainkan juga Ria Ricis dan Atta Halilintar sebagai influencer. Mereka 
mengunjungi Audrey untuk memberikan dukungan. Hotman Paris Hutapea selaku pengacara kondang pun ikut turun tangan dalam kasus ini. Namun, saat kemunculan tagar \#Audrey Juga Bersalah\# pada hari Jumat 12 April 2019, semua pengguna internet dibuat menjadi bingung. Melalui tagar itu terkuak rekam jejak digital seorang Audrey yang ternyata juga suka menebar postingan sarkas, kotor, dan tidak layak dilontarkan oleh pelajar seusianya.

Melalui penjelasan di atas dapat dikatakan bahwa baik Ratna maupun Audry telah melakukan kebohongan publik karena setelah diselidiki mereka berdua tidak pernah mendapat perlakuan yang kurang baik dari pihak-pihak tertuduh. Dengan demikian, berita yang mereka sebar lewat berbagai media dapat dikatakan sebagai berita hoax. Melalui peristiwa tersebut muncul di benak kita pertanyaan, sudah sebegitu parahkah karakter masyarakat kita? Apakah kejujuran sudah sulit untuk dilakukan, baik oleh orang dewasa maupun anak-anak? Yang lebih disayangkan jika virus ketidakjujuran merasuk ke dalam jiwa anak-anak yang kelak sebagai penerus bangsa. Apa jadinya jika negeri ini dipimpim oleh orang-orang yang tidak memiliki karakter jujur.

Berdasarkan hal-hal di atas maka dalam tulisan ini akan diangkat masalah yang berkaitan dengan hoax, karakter, dan pembelajaran sastra. Apakah hoax erat hubungannya dengan karakter? Dapatkah hoax ditepis melalui pembelajaran sastra? Berikut ini akan dikupas terlebih dahulu masalah hoax.

\section{Berita Bohong (Hoax)}

Saat ini banyak orang memanfaatkan media sosial untuk berinovasi dan berkreasi. Tidak jarang pula pengguna media sosial memanfaatkannya untuk beberapa hal, misalnya, untuk mengaktualisasikan diri, mendekatkan diri dengan keluarga, mencari penghasilan. Namun, ironisnya, di sisi lain ada juga orang atau sekelompok orang yang memanfaatkan media sosial untuk melakukan kejahatan atau hal-hal yang merugikan. Salah satu bentuk kejahatan yang ada di media sosial, yaitu adanya usaha dari seseorang atau sekelompok orang untuk memunculkan dan membagikan berita hoax.

Berita bohong (hoax) di era digital dengan mudahnya tersebar. Hoax menjadi bagian tidak terpisahkan dari pengguna teknologi dan media sosial. Dikatakan oleh Debora Sormin (dalam Purwaningsih, tt:1) bahwa sebuah berita dikatakan hoax jika mengandung unsur penyimpangan informasi, dramatisasi fakta, serangan privasi, pembunuhan karakter, dan meracuni pikiran anak. Hoax dapat dikatakan sebagai informasi yang dapat berpotensi memecah belah masyarakat dan 
sangat merugikan semua pihak. Dikatakan oleh Septanto (2018:157) bahwa hoax atau berita bohong adalah salah satu bentuk cyber crime yang kelihatannya sederhana, mudah dilakukan, tetapi berdampak sangat besar bagi kehidupan sosial masyarakat. Kedua pendapat tersebut mengisyaratkan bahwa hoax dapat dikatakan sebagai pembunuhan karakter dalam bentuk cyber crime. Hoax tidak saja dapat merugikan diri sendiri, tetapi juga merugikan orang banyak.

Melalui paparan di atas terlihat bahwa berita hoax dapat dengan mudahnya tersebar serta menyulut emosi seseorang atau kelompok orang. Hal ini berarti bahwa hoax merupakan ancaman bagi masyarakat pengguna media sosial. Hoax tidak mengenal orang tua, dewasa, ataupun anakanak karena hoax dapat dilakukan oleh siapa pun. Yang sangat memprihatinkan jika hal itu dilakukan oleh anak-anak, seperti yang dilakukan oleh Audrey. Oleh karena itu, perlu dilakukan tindakan yang dapat mencegah berkembangnya hoax, yaitu melalui pendidikan karakter dan pembelajaran sastra.

\section{Perlunya Pendidikan Karakter}

Tidak dapat dimungkiri bahwa kondisi moral negeri ini sangat memprihatinkan. Berbagai kasus pelanggaran, penyelewengan, korupsi, tindak asusila, penyebaran berita hoax, dan tindakan tidak terpuji lainnya banyak dilakukan oleh masyarakat negeri ini. Bahkan berita, baik di televisi, media cetak, maupun di media online sering mempertontonkan tindakan tidak terpuji dari para pejabat dan juga para public figure. Yang lebih menyedihkan lagi, yaitu oknum penegak hukum pun tidak terbebas dengan kasus-kasus yang sudah disebutkan di atas. Salah satu kasus yang sangat marak beberapa waktu yang lalu, yaitu penyebaran berita hoax. Tentu saja orang yang suka menebar berita hoax bukanlah orang yang berkarakter baik. Karakter seperti itu tidak saja merugikan diri sendiri, tetapi juga orang lain. Oleh karena itu, perlu keteladanan dari berbagai pihak untuk mengatasi hal tersebut.

Orang yang patut menjadi teladan dan anutan di negeri ini antara lain: para orang tua, pejabat, public figure, dan guru. Mereka merupakan orang-orang yang sepatutnya menjadi teladan bagi masyarakat karena peran mereka sangat signifikan bagi generasi muda, terutama anak-anak di era milenial. Namun, apa yang terjadi di negeri ini? Banyak tindakan mereka yang tidak pantas untuk dicontoh, misalnya, yang pernah terjadi pada era reformasi. Pada era tersebut, reformasi dimaknai secara 'kebablasan' sehingga banyak dari masyarakat yang bebas berbuat apa saja tanpa aturan. Banyak yang melanggar 
berbagai norma, seperti norma agama, sosial, susila.

Hal semacam itu semakin menjadi parah ketika bangsa ini memasuki era milenial. Di era tersebut segala hal dapat diakses dengan mudah melalui media sosial sehingga segala hal yang dilakukan orang dewasa sering ditiru oleh anak-anak. Mereka dapat dikatakan sebagai peniru ulung. Anak-anak yang jiwanya masih polos dengan mudahnya meniru sikap atau karakter yang kurang baik dari orang dewasa dan para orang tua. Dengan demikian, karakter bangsa ini di era tersebut tidak menunjukkan gejala yang lebih baik, tetapi justru sebaliknya. Kejujuran, kedisiplinan, dan juga tanggung jawab sebagai karakter yang utama bagi seseorang, saat ini sulit ditemukan.

Hilangnya salah satu karakter utama, yaitu karakter jujur dapat berimbas ke karakter buruk lainnya, seperti tidak disiplin, tidak amanah, suka menipu, suka bohong, dan lain-lain. Menipu dan menyebar berita bohong merupakan karakter yang justru banyak berkembang di media sosial. Melalui media tersebut orang dengan mudah melakukan penipuan maupun kebohongan. Mereka, baik para orang tua, dewasa, maupun anak-anak sudah terkena virus tersebut. Kondisi ini jelas akan merusak karakter anak bangsa di kemudian hari. Bangsa ini tidak akan lagi dikenal sebagai bangsa yang berbudi luhur karena para orang tua, pejabat, dan public figure telah mencontohkan karakter buruk bagi anak-anak sebagai penerus bangsa. Dengan demikian, agar karakter bangsa ini tidak terpuruk lebih dalam lagi, diperlukan adanya pendidikan karakter.

Dikatakan oleh Sarwiji (2013:2) bahwa karakter pada dasarnya berasal dari nilai yang diwujudkan dalam bentuk perilaku. Dalam referensi Islam, nilai yang sangat terkenal melekat dan mencerminkan akhlak Nabi Muhammad SAW, yaitu sidik, amanah, fatonah, dan tablig. Sidik berarti benar, berkomitmen pada kebenaran, selalu berkata dan berbuat benar, dan berjuang menegakkan kebenaran. Amanah berarti jujur atau terpercaya (baik oleh kaum muslim maupun nonmuslim). Fatonah berarti cerdas, pandai, arif, berwawasan luas, terampil, dan profesional. Tablig berarti komunikatif (orang lain mudah memahami yang dibicarakan atau dimaksudkan Rasulullah). Keempat nilai tersebut jika diterapkan dan dilaksanakan dalam kehidupan, setidaknya dapat membentuk manusia Indonesia yang purnawan, manusia dengan karakter seperti dimiliki Nabi Muhammad SAW.

$$
\text { Dalam Kemendiknas }
$$

disebutkan bahwa karakter adalah watak, tabiat, akhlak, atau kepribadian seseorang yang terbentuk dari hasil internalisasi berbagai kebajikan (virtues) yang diyakini dan digunakan sebagai landasan untuk cara 
pandang, berpikir, bersikap, dan bertindak. Lickona dalam Muslich menekankan tiga komponen karakter yang baik dan harus ditanamkan sejak dini, yaitu moral knowing (pengetahuan tentang moral), moral feeling (perasaan tentang moral), dan moral action (perbuatan moral).

Berdasarkan hal-hal di atas dapat dinyatakan jika bangsa ini menginginkan karakter generasi muda dapat selaras dengan kepribadian bangsa Indonesia, diperlukan pendidikan karakter. Pendidikan tersebut harus ditanamkan sejak usia dini baik oleh orang tua, guru, maupun pemerintah. Pendidikan karakter merupakan pendidikan yang mengembangkan nilai-nilai karakter bangsa pada diri peserta didik sehingga mereka memiliki nilai dan karakter sebagai karakter dirinya. Peserta didik diharapkan dapat menerapkan nilai-nilai tersebut dalam kehidupan dirinya sebagai anggota masyarakat dan warga negara yang religius, nasionalis, produktif, dan kreatif. Tujuan akhir dari pelaksanaan pendidikan karakter sebagaimana disampaikan Battistich (2010:3) utamanya adalah meningkatkan kebaikan dalam diri peserta didik, yaitu menjadi anak muda yang cerdas, peduli, dan mengutamakan nilai-nilai kebajikan dalam setiap perbuatannya.

Keluarga memiliki peran penting dalam pendidikan karakter. Seluruh anggota keluarga seidaknya memiliki persepsi, sikap, dan pola tindak yang sama dalam pengembangan karakter anak. Orang tua perlu menjadi contoh dalam penegakan tata tertib dan etiket/budi pekerti dalam keluarga sebagai penguatan perilaku berkarakter kepada anak. Selain itu, orang tua perlu menjalin komunikasi yang efektif dengan guru di sekolah. Dengan cara seperti itu, anak akan tumbuh menjadi manusia purnawan yang berakhlak mulia.

Lembaga Pendidikan, seperti dikatakan Sarwiji (2013:4) memiliki peranan yang sangat besar dalam pendidikan karakter. Pendidikan diyakini sebagai tempat penanaman nilai-nilai luhur kehidupan, penyemaian nilai-nilai baru yang disepakati oleh masyarakat, dan tempat melestarikan nilai-nilai luhur ke depan. Di sekolah, pendidikan karakter dapat diintegrasikan dalam pembelajaran pada setiap mata pelajaran. Materi pembelajaran yang berkaitan dengan norma atau nilai-nilai pada setiap mata pelajaran perlu dikembangkan, dieksplisitkan, dikaitkan dengan konteks kehidupan sehari-hari. Dengan demikian, pembelajaran nilai-nilai karakter tidak hanya pada tataran kognitif, tetapi juga menyentuh pada internalisasi, dan pengamalan nyata dalam kehidupan peserta didik sehari-hari di masyarakat.

Berkaitan dengan hal di atas maka upaya perbaikan karakter bangsa yang 
sedang mengalami degradasi moral harus segera dilakukan.Tentu saja diperlukan kepedulian dari berbagai pihak, baik pemerintah, masyarakat, keluarga maupun sekolah. Salah satu upaya yang dapat dilakukan, yaitu melalui pendidikan karakter. Upaya ini, selain menjadi bagian dari proses pembentukan akhlak siswa, juga dimaksudkan agar peserta didik dapat bersikap santun dalam segala ucapan, sikap, dan perilaku. Dalam Undang-Undang Nomor 20 Tahun 2003 disebutkan "Pendidikan Nasional berfungsi mengembangkan kemampuan dan membentuk watak serta peradaban bangsa yang bermartabat dalam rangka mencerdaskan kehidupan bangsa, bertujuan untuk berkembangnya potensi peserta didik agar menjadi manusia yang beriman dan bertakwa kepada Tuhan Yang Maha Esa, berakhlak mulia, sehat, berilmu, cakap, kreatif, mandiri, dan menjadi warga negara yang demokratis serta bertanggung jawab. Undang-undang tersebut jelas memuat pendidikan karakter yang harus dicapai oleh lembaga pendidikan.

T. Ramli (dalam Zainal Aqib dan Sujak, 2011: 3) menyebutkan bahwa pendidikan karakter memiliki esensi dan makna yang sama dengan pendidikan moral dan pendidikan akhlak. Tujuannya, yaitu membentuk pribadi anak supaya menjadi manusia yang baik, warga masyarakat, dan warga negara yang baik. Dengan demikian, hakikat dari pendidikan karakter dalam konteks pendidikan diIndonesia adalah pendidikan nilai, yakni pendidikan nilainilai luhur yang bersumber dari budaya bangsa Indonesia sendiri dalam rangka membina kepribadian generasi muda.

Pendidikan karakter merupakan segala sesuatu yang dilakukan guru untuk memengaruhi karakter peserta didik. Guru membantu dalam membentuk watak peserta didik dengan cara memberikan keteladanan, cara berbicara atau menyampaikan materi yang baik, toleransi, dan berbagai hal yang terkait lainnya (Asmani, 2011:31). Lebih lanjut dikatakannya, nilai-nilai karakter dapat dikelompokkan menjadi lima nilai utama, yaitu nilai-nilai perilaku manusia dalam hubungannya dengan Tuhan Yang Maha Esa, diri sendiri, sesama manusia, lingkungan, dan kebangsaan. Menurut Widihastuti (2013:40), “Karakter seseorang dapat dibedakan menjadi dua, yaitu karakter yang baik (positif atau good character) dan karakter yang tidak baik (negative). Keduanya dapat melekat pada diri seseorang, bergantung pada lingkungan yang memengaruhinya". Umumnya istilah karakter sering dihubungkan atau mengacu pada karakter positif, misalnya terdapat istilah pendidikan karakter. Dalam istilah tersebut jelas karakter positiflah yang diinginkan, bukan karakter negatif.

Berdasarkan pembahasan di atas dapat disimpulkan bahwa pendidikan 
karakter merupakan pendidikan yang diberikan kepada siswa agar siswa memiliki kepribadian atau karakter yang luhur, mempunyai akhlak dan moral yang mulia, serta berani mempertanggungjawabkan atas akibat yang telah diperbuat. Melalui pendidikan karakter diharapkan, karakter siswa ke depannya lebih baik. Dalam arti, siswa memiliki karakter jujur, tidak suka berbohong dan tidak suka menebar hoax. Oleh karena itu, untuk menginternalisasikan pendidikan karakter pada diri siswa maka budaya literasi adalah solusinya. Salah satunya melalui pembelajaran sastra.

\section{Pembelajaran Sastra}

Gerakan Literasi Sekolah (GLS) yang saat ini tengah digalakkan sangat mendukung upaya mengatasi hoax. Gerakan ini perlu dimanfaatkan sebaikbaiknya oleh siswa maupun guru. Guru mengajak siswa meluangkan waktunya untuk membaca. Membaca merupakan salah satu aktivitas dari pembelajaran yang harus diperhatikan guru. Selain itu, guru perlu menekankan kepada siswa bahwa membaca tidak hanya dilakukan di kelas, tetapi juga dapat dilakukan di mana saja. Siswa perlu dibiasakan untuk membaca berita dari berbagai sumber. Guru juga perlu berpartisipasi aktif dalam memberi keteladanan penerapan budaya literasi di sekolah. Artinya, guru pun tidak hanya bisa menyuruh siswa, tetapi juga harus melakukan kegiatan membaca.

Program GLS harus dipantau secara terus-menerus, baik oleh guru maupun pihak sekolah agar dapat berjalan secara teratur dan berkelanjutan. Melalui GLS, paling tidak siswa memiliki pertahanan yang kuat sehingga tidak mudah menjadi korban maupun pelaku penyebaran hoax. Kesadaran untuk membaca harus ditanamkan dalam diri siswa sejak dini. Jika siswa tidak suka membaca, akibatnya siswa akan miskin informasi. Miskinnya informasi mengakibatkan siswa sulit memilah-milah mana yang hoax dan mana yang bukan. Sebaliknya, jika siswa terbiasa membaca, ia akan lebih mudah mengenali hoax.

Kehadiran sastra memang tidak bisa terlepas dari kehidupan manusia dan juga masyarakat. Karya sastra menggambarkan realitas yang ada di dalam masyarakat. Di dalam karya sastra akan ditemukan berbagai karakter tokoh. Melalui karakter tokoh, siswa akan mendapatkan nilai-nilai luhur. Dengan kata lain, karya sastra tidak hanya membentuk watak dan moral siswa, tetapi juga dapat memupuk kecerdasan siswa dalam berbagai aspek. Dengan demikian, sastra dapat dijadikan sebagai sarana yang tepat untuk menanamkan dan mengembangkan berbagai nilai yang ingin diwariskan kepada siswa. Melalui sastra, siswa akan lebih mudah untuk menyerap 
berbagai nilai yang berkaitan dengan moral, etika, akhlak, budi pekerti, dan lain-lain karena ada figur/tokoh yang dicontoh Tentu saja siswa harus diarahkan untuk meneladani karakter tokoh yang baik.

Kurniawan (2009:21) mengatakan bahwa ada dua hal utama yang terdapat dalam sastra, yaitu nilai dan keindahan. Aspek nilai inilah yang kemudian disebut makna. Sastra selalu menyampaikan nilai atau makna kepada pembaca. Makna dalam sastra dinamakan amanat atau pesan. Amanat atau pesan tersebut dalam karya sastra selalu mempunyai kandungan nilai moral. Artinya sastra dapat dijadikan sarana untuk membelajarkan karakter yang sesuai dengan nilai-nilai kehidupan. Karya sastra yang berisi nilai-nilai moral mengacu pada pengalaman manusia dalam melakukan segala tindakan dan sikap merupakan sarana yang baik untuk pembentukan karakter. Salah satu caranya, yaitu dengan memasukkan karya sastra dalam pembelajaran.

Melalui pembelajaran sastra, guru dapat merealisasikan pendidikan karakter karena di dalam mengapresiasi sastra, siswa langsung berhadapan dengan bermacam-macam nilai kehidupan yang diemban oleh para tokoh, di antaranya nilai religius, kejujuran, toleransi, cinta kasih, keadilan, pengabdian, dan sebagainya. Dengan nilai-nilai yang terdapat di dalam sastra, paling tidak siswa dapat menginternalisasikan ke dalam dirinya sehingga siswa terhindar dari perbuatan menebar hoax. Perbuatan tersebut tidak hanya merugikan diri sendiri. tetapi juga akan merugikan orang banyak. Bentuk pendidikan karakter akan lebih hidup dan lebih konkret melalui pembelajaran sastra sehingga berguna bagi peserta didik. Peserta didik dapat menginternalisasi-kan sekaligus menerapkan nilai-nilai yang didapat melalui sastra dalam hidup keseharian mereka secara praktis dalam bentuk keberpihakan terhadap nilai-nilai yang positif.

\section{Simpulan}

Hoax (berita bohong) merupakan salah satu bentuk kejahatan yang dilakukan melalui media sosial. Hoax bukan hanya merugikan diri sendiri, melainkan juga merugikan banyak orang. Orang yang sering membuat hoax menandakan bahwa orang tersebut memiliki karakter yang kurang baik. Hoax tidak saja dilakukan oleh orang dewasa saja, tetapi juga anak-anak. Kondisi ini sangat memprihatinkan karena anak-anak calon generasi penerus memiliki karakter kurang baik. Anak-anak sudah menjadi biasa dan terbiasa melakukan kebohongan. Seolah-olah perbuatan tersebut merupakan perbuatan yang menyenangkan. Oleh karena itu, untuk mencegahnya perlu adanya pendididikan karakter. 
Pendidikan karakter merupakan pendidikan yang diberikan kepada siswa agar siswa memiliki kepribadian atau karakter yang luhur serta mulia, seperti jujur, tidak suka berbohong, tidak suka menebar hoax serta berani bertanggung jawab atas perbuatan yang telah dilakukannya. Melalui pendidikan karakter diharapkan, karakter siswa ke depannya lebih baik. Pendidikan karakter akan lebih berhasil jika dibarengi dengan budaya literasi. Misalnya, dengan membaca sastra. Melalui sastra, siswa akan lebih mudah menyerap berbagai nilai yang berkaitan dengan moral, etika, akhlak, budi pekerti karena ada figur/tokoh yang dicontoh. Dengan demikian, dapat dikatakan bahwa karya sastra dapat digunakan sebagai alat untuk menepis hoax.

\section{Daftar Rujukan}

Asmani, Jamal Ma'mur. 2011. Buku Panduan Internalisasi Pendidikan Karakter di Sekolah. Yogyakarta: DIVA Press.

Aqib, Zainal dan Sujak. 2011. Panduan \& Aplikasi Pendidikan Karakter. Bandung: Yama Widya

Battistich, Victor. 2010. "Character Education, Prevention, and Positive Youth Development". (Daring). Tersedia:

http://www.rucharacter.org/file/Battistich\%20Paper.pdf. (2 Agustus 2019).

Kesuma, Dharma, Cepi Triatna, dan Johan Permana. 2011. Pendidikan Karakter Kajian Teori dan Praktik di Sekolah. Bandung: PT Remaja Rosdakarya.

Kurniawan, Heru. 2009. Sastra Anak dalam Kajian Strukturalisme, Sosiologi, Semiotika, hingga Penulisan Kreatif. Yogyakarta: Graha Ilmu.

Purwaningsih, Dwi.tt. Budaya Literasi Solusi Melawan Hoax: Antihoax Sang Pendidik. (Daring). Tersedia: https://www.kompasiana.com/dwip/5a03044ba208c046162c2c42/anti-hoax-sangpendidik. (15 April 2019).

Sarwiji. 2013. Peran Guru Bahasa Indonesia yang Inspiratif untuk Mewujutkan Peserta Didikyang Berkarakter. Dalam Proceeding Seminar Internasional Pertemuan Ilmiah Bahasa dan Sastra Indonesia (PIBSI) XXXV.

Septanto, Henri, 2018. Pengaruh Hoax dan Ujaran Kebencian Sebuah Cyber Crime dengan Teknologi Sederhana di kehidupan social Masyarakat. Jurnal Kalbi Scientia Vol.5 (2): 157 
Widihastuti, dalam Jurnal Pendidikan Karakter, Tahun III, Nomor 1, Februari 2013.Yogyakarya: Lembaga Pengembangan dan Penjaminan Mutu Pendidikan (LPPMP) Universitas Negeri Yogyakarta. 